\title{
Dangers, Delights, Development: Female Travel in The Mysteries of Udolpho and The Turkish Embassy Letters
}

\author{
Julia Stanski
}

Department of English and Film Studies, University of Alberta, Edmonton, Alberta

Corresponding author: jstanski@ualberta.ca

\section{ABSTRACT}

This paper examines the portrayal of travel for women in two eighteenth-century literary texts by women writers: The Mysteries of Udolpho by Ann Radcliffe and The Turkish Embassy Letters by Lady Mary Wortley Montagu. With a focus on the emotional and psychological effects of female travel that each author depicts, the article analyzes both the dramatic dangers and pleasures faced by Radcliffe's Gothic heroine and the more mild, cerebral ones experienced by the historical Montagu. Drawing on the work of Marianna D'Ezio, Adam Watkins, and Mary Jo Kietzman, I argue that both Radcliffe and Montagu ultimately endorsed the idea of travel for women through their work by portraying the pleasure, experience, and self-cultivation it afforded as outweighing its dangers. Finally, I posit that this position resisted both Enlightenment and Romantic ideas of appropriate female behaviours and desires by encouraging women readers to experience the world outside of the domestic sphere.

Lady Mary Wortley Montagu and Ann Radcliffe wrote in different genres, at opposite ends of the eighteenth century, and on vastly different subjects; however, both authors' work at some point dealt with the topic of travel and its enlightening effects for women. Montagu's The Turkish Embassy Letters chronicles her own two-year trip through Europe and the Ottoman Empire in 1716-1718, and Radcliffe's 1794 Gothic novel The Mysteries of Udolpho features a young heroine on extended journeys through Italy and France. Examining these female-authored texts from two different time periods allows us to track the differences in the way women thought about travel during the Enlightenment versus the Romantic period. Furthermore, comparing a nonfiction travelogue to a Gothic novel highlights the fundamental similarities between the thought of Radcliffe and Montagu despite their significant authorial differences. While Udolpho emphasizes the mental and emotional dangers that travel presents for women, Montagu's text engages with these risks more briefly and cerebrally. However, both writers ultimately present the mental benefits of travel for women as outweighing its dangers, hence endorsing women's travelling through their work.

Although the heroines of Udolpho and Embassy Letters experience many types of risks and opportunities throughout their travels, I have chosen to focus on the mental, emotional, and psychological aspects of their journeys. I believe these aspects to be important because female travellers in the eighteenth century could engage with them directly and personally. While a male travelling companion could mediate, for example, the physical dangers or social opportunities that a lady experienced during a voyage, he could

SPECTRUM | INTERDISCIPLINARY UNDERGRADUATE RESEARCH 
not control how she dealt with the emotional risks or mental benefits the trip offered. Women could choose to fully indulge in them, or to resist them almost entirely. I believe that the mental, emotional, and psychological aspects of travel provided both Radcliffe's fictional protagonist Emily St. Aubert and the historical Montagu with space for agency in reacting to them

In Radcliffe's Udolpho, Emily encounters many dangers to her mental well-being as soon as she leaves her home. When she travels into Languedoc and Gascony with her father, these mainly take the form of near-constant "anxiety" $(39,47)$; concerns over her father's health, bandits, getting lost, and finding a place to stay for the night keep her in a state of almost perpetual worry. She also comes across scenes on this journey that remind her of her deceased mother and temporarily exacerbate her grief. For example, when Emily and her father discover a view that resembles "a favourite one of the late Madame St. Aubert," "[t]hey both . . thought how delighted she would have been with the present landscape, while they knew that her eyes must never, never more open upon this world" (29), a reflection that brings them great pain.

After her father's death, Emily is forced to travel to Udolpho, the distant mountain castle of her aunt's sinister new husband. Upon learning this, she immediately suffers from fear and dread. "The idea of this desolate castle" causes "her sick heart [to] recoil . . . in despair" (225), and once she reaches it, the dangers to her psychological state increase dramatically. The knowledge that she is trapped in the remote fortress, "beyond the reach of law or justice" (435), is a regular source of terror and despondence for her, and when her aunt disappears, Emily endures "exhausting suspense" (319) as she agonizes over her aunt's possible fate. Emily also undergoes many traumatic experiences in Udolpho, including two abduction attempts, men pursuing her through the castle at night, and the threat of sexual violence, all of which damage the "tone" (249) of her spirits and cause her great "apprehensions" (335) for her safety. In this tense and fearful state, Emily begins to have trouble controlling her imagination; "[t]he influence of superstition now gained on the weakness of her long-harassed mind" (355), and she sporadically gives in to belief in specters against her better judgment. But it is the terrifying sights she encounters within the walls of Udolpho, including a bloody corpse and a lifelike model of a worm-eaten body, that have the most dangerous effect on her mind. Both these sights and her fear of disclosing them to anyone push her to the brink of madness. After discovering a blooddrenched dead body, when she is "compelled to bear within her own mind the whole horror of the secret," "her reason seemed to totter under the intolerable weight. She often fixed a wild and vacant look on [her servant], and, when she spoke, either did not hear her, or answered from the purpose" (350). From terror to trauma to exhaustion to insanity, there are very few mental and emotional dangers that Emily does not encounter as a result of her travels.

In contrast, Montagu writes about only a few mental dangers that she experiences as a result of her voyage. These risks are more intellectual ones, befitting both the fact that Montagu was writing during the Enlightenment instead of the excessive Romantic period of Radcliffe, and that her text is a non-fiction travelogue rather than a Gothic novel. The first danger she mentions is that of becoming so immersed in other cultures that she loses the ability to function in her own culture as an Englishwoman. In letter \#41, she notes that as a result of her study and practice of multiple other languages while in Turkey, "I am in great danger of losing my English" (163).

Montagu also suggests that in various ways, travel risks making one less content with one's own situation. When contemplating her return to England, she indicates that "rambling" and exposure to the customs of various societies have given her a frustrating and "fruitless desire of mixing the different pleasures and conveniences which are given to different parts of the world and cannot meet in any one of them" (213). In 
addition, Montagu implies that having experienced a life of relative comfort and ease in Turkey, she wishes she could remain there. In letter \#43, she confesses that she is preparing to leave Turkey "with regret:" "I am used to the air and have learnt the language. I am easy here" (170). Letter \#52 concludes with the rueful line "I pray God . . . since I must be contented with our scanty allowance of daylight, that I may forget the enlivening sun of Constantinople" (214). This illustrates that her life in England now appears much less attractive to her in contrast to the past year. By travelling, Montagu has endangered her peace of mind and satisfaction with the circumstances in which she must live.

However, despite these presentations of its dangers, Radcliffe and Montagu by no means portray travel for women as a wholly negative experience. Both Emily and Lady Mary enjoy many psychological benefits during their journeys, which arguably outweigh the risks they face. Notwithstanding the fact that Emily generally travels by necessity rather than voluntarily, on her voyages she receives countless opportunities to appreciate both beautiful and sublime scenery and to experience the emotional and spiritual uplift that it evokes. As she travels through France to Italy and back again, Emily often feels the pleasure of "that pure devotion ... which lifts the soul above this world, and seems to expand it into a nobler nature" (48).

One can also argue that Emily's mind expands as a result of her travels, as does her perspective and her sensibility. Dr. Adam Watkins, a scholar of environment and identity in literature, claims that while Emily's father taught her to espouse the dichotomy of pure, wholesome country life versus decadent, corrupt urban life, Emily finds the city of Venice to be beautiful and stimulating as well as dissipated. Her experience there complicates this binary and allows her to discover "the capacity of urban splendor to expand the mind and spur the imagination" towards a poetic "mode of vision" (Watkins 590, 592). For example, when Emily watches a procession of decorated boats on the Grand Canal, "the fanciful images, which it awakened in Emily's mind, lingered there long after the procession had passed away" (Radcliffe 178). "Enchanting" (177) sights like this one stimulate Emily's imagination powerfully enough that it begins to shape her perception. From this point forward she is able to "conflate the imaginary and the real in sustained and meaningful ways," and to see the world as a "visionary poet" does (Watkins 592). Watkins argues that this is an important step towards achieving the ideal sensibility demonstrated by Emily's father M. St. Aubert. As Marianna D’Ezio observes, in Venice "the 'transforming eye' which St. Aubert mentions at the beginning of the novel . . becomes Emily's tool to fully enjoy the city with all its ambiguities" (349). Like her father, Emily can now "transform reality through her imagination" (D’Ezio 350), but she can also appreciate a complicated urban space as containing more than just corruption. In this way, her experience in Venice allows her to achieve a type of imaginative sensibility that resembles her father's, while at the same time expanding her horizons beyond those of M. St. Aubert.

Furthermore, throughout her travels Emily learns how to maintain her mental health in foreign and often hostile surroundings. In Venice she appreciates the splendours of the city, but she also develops a strategy to preserve her peace of mind in urban environments and around urban people. Notably, when she arrives at the Venetian mansion of her aunt's husband, she "endeavour[s] to enliven" her aunt; but when she is met only with "caprice and ill-humour", she "withdr[aws] to a lattice, to amuse herself with the scene without" (177). While Emily has taken refuge at windows before, from this point forward she does so when confined in a building in an urban environment, to "refresh" (416) her spirits and distract herself from the depressing or frightening influence of the people and space around her.

This pattern of behaviour is visible throughout Emily's stay at Udolpho. Watkins contends that the castle of Udolpho functions as an urban space for Emily; its rambling corridors simulate a maze of streets in 
which violence and dissipation occur, and where she is constantly confronted with strange men. Most importantly, it is a confining space in which Emily cannot interact with nature, which was the strategy she used at home to soothe her mental distress $(96,100,113)$. Therefore, in this space in which she is often "haunted by the most dismal images" occasioned by her "long anxiety" (Radcliffe 329), Watkins notes that Emily frequently goes to a casement or window to observe the natural landscape and "relieve her mind from the busy ideas that tormented it," "amuse her fancy" (241), or "vanquish the phantoms, that tormented her" (329). By using this strategy, Emily is able to maintain her sanity amid the psychological dangers of the prisonlike Udolpho, and gains an important coping skill that may contribute to her mental resilience throughout the rest of her life.

The mental benefits that Lady Mary gains throughout her travels are, again, more cerebral and less dramatic ones than Emily's. She enjoys the novelty and beauty of the places she visits, from Rotterdam to Adrianople to Belgrade-Village, but most importantly she takes advantage of the chance that travel affords her to expand her mind. She records the history of the places through which she passes, studies the Turkish language, and learns about Turkish poetry, taking more pleasure in these intellectual pursuits than in the social frivolities of London life (147). Montagu also seizes the opportunity to compare the manners and customs of other societies to those of England and assess which ones are more advantageous. For example, in letter \#43 she comments unfavorably on the English practice of leaving one's property to one's nearest male relative ("a creature without other merit or relation to me than a few letters") compared to the Turkish custom of adopting "some pretty child of either sex ... to make happy and rich" as one's heir (175).

Additionally, as Mary Jo Kietzman notes, Montagu gradually attains a more multifaceted and hybrid understanding of both her own identity and the identities of the women she meets. In her interactions with Turkish women, she notices their "ability to tolerate contradictions" in their self-concept (Kietzman 544). For example, her friend Fatima understands herself as a Turkish woman who has both Christian heritage and a "Christian" appearance (Montagu 159). Through her exposure to this concept of personal hybridity, Montagu learns to apply it to herself and becomes more able to balance the apparently contradictory parts of her own identity: "mother, thinker, correspondent, and writer" (Kietzman 547). For instance, in letter \#39 Montagu is able to represent herself (apparently unproblematically) as simultaneously a mother and an intellectual, reflecting on Turkey's laws and cultural values in between references to her own pregnancy and imminent labour (Montagu 151-153; Kietzman 546).

Despite the dangers to their psychological well-being that Emily and Lady Mary face, both writers emphasize the important mental gains they achieve through their travels. Montagu clearly believes that these benefits surpass any risks she might run. Notwithstanding the few notes of regret found near the end of her letters, her writings present almost exclusively the manifold intellectual delights and benefits she enjoys on her trip, suggesting to her female readers that travel is something to be desired.

Radcliffe's text is admittedly more ambiguous about the value of travel for women, given the many serious dangers that Emily faces to her emotional and mental state while on the road. However, it is noteworthy that when Emily finally returns to the safety of her home near the end of the novel, all the threats to her stability and peace of mind that she suffered during her travels do not prevent her from travelling again. She goes to the home of her friend Blanche for a wedding only days after returning home, and after her own marriage she and her husband travel between their two estates every year for the rest of their lives. The fact that Emily is willing to continue travelling after all she has experienced suggests that both she and Radcliffe see the mental benefits she obtained 
on her travels as outweighing the dangers she faced. Additionally, when Radcliffe portrays Emily and her lover Valancourt as finally married and free from care at the novel's conclusion, she tells us that "the retrospect of all the dangers and misfortunes they had each encountered, since last they sat together . . . exalted the sense of their present felicity" (671), implying that Emily could not have reached her final state of happiness without undergoing all the perils of her travels. This phrase, in conjunction with the psychological benefits detailed above that Emily gleans from her journeys, suggests that Radcliffe sees travel as advisable and even important for women, despite its hazards to their mental and emotional state.

Based on this evidence, it appears that both Radcliffe and Montagu endorsed the idea of women travelling, valuing the opportunities it afforded them for psychological and emotional growth and enjoyment. This was a somewhat radical position for both writers, neither of whom wrote in an age when travel was seen as wholly appropriate for women. Elizabeth Bohls notes that during the Enlightenment, "the home was literally and symbolically woman's place ... Women did not fit the traveler's image as heroic explorer, scientist, or authoritative cultural interpreter" (17). The fact that Radcliffe wrote in the Romantic period, which ostensibly valued rebellion and nonconformity, might suggest that the idea of women exploring the world was more acceptable in her time. But Romantic ideals were heavily gendered, and Jacqueline Labbe observes that in this period, though "travel books were read voraciously by women and even recommended," "encouraging the reading of travels involved discouraging actual travel" (114-115). Additionally, female travellers were "rare enough that one risked attracting too much attention, and being seen as an oddity" (Labbe 114-115). In advocating for women to travel for the pleasure, experience, and self-cultivation it afforded, both Montagu and Radcliffe pushed the boundaries of appropriate behaviour and desires for women.
In conclusion, while Radcliffe's The Mysteries of Udolpho and Montagu's The Turkish Embassy Letters both explore the emotional and psychological dangers to which female travellers are vulnerable, they also present the mental benefits and opportunities of travel for women as overriding these concerns. Although Radcliffe addresses these dangers more extensively than Montagu does, both authors manage to present a relatively progressive view on acceptable behaviour for women, encouraging female readers to step beyond their socially prescribed roles and experience the world outside their homes. 


\section{Notes}

1. Throughout the paper I use the name "Montagu" when referring to Lady Mary Wortley Montagu as a writer, and "Lady Mary" in reference to the self she creates and presents as the protagonist of her letters. 


\section{Works Cited}

Bohls, Elizabeth A. Introduction. Women Travel Writers and the Language of Aesthetics, 1716-1818, by Bohls, Cambridge University Press, 1995, pp. 1-22.

D’Ezio, Marianna. "'As like As Peppermint Water is to Good French Brandy:' Ann Radcliffe and Hester Lynch Salusbury (Thrale) Piozzi." Women's Writing, vol. 22, no. 3, 2015, pp. 343-354. Academic Search Complete, DOI: https://doi.org/10.1080/09699082.2015.1037985.

Kietzman, Mary Jo. "Montagu's Turkish Embassy Letters and Cultural Dislocation." Studies in English Literature, 1500-1900, vol. 38, no. 3, 1998, pp. 537-551. Academic Search Complete, DOI: https://doi.org/10.2307/451062.

Labbe, Jacqueline M. " 'A species of knowledge both useful and ornamental': Travelling the Romantic Landscape." Romantic Visualities: Landscape, Gender and Romanticism, Palgrave Macmillan, 1998, pp. 113-148.

Montagu, Lady Mary Wortley. The Turkish Embassy Letters, edited by Teresa Heffernan and Daniel O'Quinn, Broadview Editions, 2013.

Radcliffe, Ann. The Mysteries of Udolpho, edited by Bonamy Dobrée, Oxford University Press, 1988. Watkins, Adam Edward. "Environmental Self-making and the Urbanism of Ann Radcliffe's Udolpho." European Romantic Review, vol. 28, no. 5, 2017, pp. 585-600. Academic Search Complete, DOI: https://doi.org/10.1080/10509585.2017.1362344. 